\title{
Control of postharvest gray mold of 'BRS Nubia' table grape under cold storage
}

\section{Controle de mofo cinzento na pós-colheita da uva de mesa 'BRS Nubia' sob armazenamento refrigerado}

\author{
Ronan Carlos Colombo ${ }^{*}$; Deived Uilian de Carvalho²; Maria Aparecida da Cruz²; \\ Ciro Hideki Sumida ${ }^{3}$; Saeed Ahmed ${ }^{4}$; Muhammad Shahab ${ }^{5}$; Sergio Ruffo Roberto ${ }^{3}$
}

\section{Highlights:}

Gray mold control on 'BRS Nubia' table grapes can be achieved using an $\mathrm{SO}_{2}$ pads.

'BRS Nubia', a novel table grape, may be stored for up to 30 days under cold storage.

$\mathrm{SO}_{2}$ pads do not affect the chemical characteristics of grape berries.

\begin{abstract}
The demand for high-quality nutritional products has increased fruit consumption, as grapes, for this reason postharvest techniques are required to prevent losses, to preserve quality, to extend shelf life, and to attend to consumer needs. In this way, the objective of this study was to evaluate strategies to control gray mold caused by Botrytis cinerea in 'BRS Nubia' grapes during cold storage and shelf life periods. Grape bunches were harvested from a commercial vineyard in Marialva, Parana, Brazil. Grapes were subjected to the following treatments: cold storage at $2{ }^{\circ} \mathrm{C}$ (control), cold storage at $2{ }^{\circ} \mathrm{C}$ with $\mathrm{SO}_{2}$ generating pads, cold storage at $2{ }^{\circ} \mathrm{C}$ and inoculated with $B$. cinerea suspension, and cold storage at $2{ }^{\circ} \mathrm{C}$ with $\mathrm{SO}_{2}$-generating pads and inoculated with $B$. cinerea suspension. The experiment was conducted in a complete randomized design with five replications per treatment using four bunches per experimental unit. A factorial arrangement (absence/presence of $\mathrm{SO}_{2}$ pads $\times$ absence/presence of Botrytis inoculation) was applied. At the end of 30 days of cold storage and 7 days of shelf life $\left(22^{\circ} \mathrm{C}\right)$, gray mold incidence, shattered berries, and physicochemical parameters were evaluated. The gray mold incidence on 'BRS Nubia' grapes decreased when $\mathrm{SO}_{2}$-generating pads were used during cold storage. Berry weight loss was greater in the treatments without $\mathrm{SO}_{2}$-generating pads after 30 days of cold storage followed by 7 days of shelf life. Berry firmness, soluble solids content (SS), total acidity (TA), SS/TA ratio, and anthocyanins concentration were not negatively affected by $\mathrm{SO}_{2}$-generating pad treatments. However, a slight increase in the shattered berries percentage was recorded for the $\mathrm{SO}_{2}$-generating pad treatments. No significant quality loss of 'BRS Nubia' grape was evident after 30 days of cold storage followed by 7 days of exposure at room temperature. In this context, $\mathrm{SO}_{2}$-generating pads can be used to control the gray mold incidence on 'BRS Nubia' table grapes during cold storage.
\end{abstract}

Key words: Botrytis cinerea. Fruit quality. Sulfur dioxide.

\footnotetext{
1 Prof. Dr., Departamento Acadêmico de Ciências Agrárias, Universidade Tecnológica Federal do Paraná, UTFPR, Francisco Beltrão, PR, Brasil. E-mail: ronancolombo@utfpr.edu.com.br

2 Discentes do Curso de Doutorado do Programa de Pós-Graduação em Agronomia, Universidade Estadual de Londrina, UEL, Londrina, PR, Brasil.E-mail: deived10@gmail.com; mary_ac18@hotmail.com

3 Profs. Drs., Departamento de Agronomia, UEL, Londrina, PR, Brasil. E-mail: cirosumida@hotmail.com; sroberto@uel.br

4 Prof. Dr., Departamento de Horticultura, Gomal University, Dera Ismail Khan, Paquistão. E-mail: saeeddikhan@gmail.com

5 Prof. Dr., University of Swabi, KP, Paquistão. E-mail: mshahab78@gmail.com

* Author for correspondence
} 


\section{Resumo}

A demanda por produtos de alta qualidade nutricional tem aumentado o consumo de frutas, como as uvas, por esse motivo, são necessárias a adoção de técnicas pós-colheita para evitar perdas, preservar a qualidade e prolongar a vida útil, além de atender às necessidades do consumidor. Dessa forma, o objetivo deste estudo foi avaliar estratégias para o controle do mofo cinzento causado por Botrytis cinerea em uvas 'BRS Nubia' durante o armazenamento refrigerado e a vida de prateleira. Cachos da uva 'BRS Nubia' foram colhidos em um vinhedo comercial localizado em Marialva, Paraná, Brasil. As uvas foram submetidas aos seguintes tratamentos: armazenamento refrigerado à $2{ }^{\circ} \mathrm{C}$ (controle); armazenamento refrigerado à $2{ }^{\circ} \mathrm{C}$ com folha geradora de $\mathrm{SO}_{2}$; armazenamento refrigerado à $2{ }^{\circ} \mathrm{C}$, inoculado com suspensão de $B$. cinerea; e armazenamento refrigerado à $2{ }^{\circ} \mathrm{C}$ com folha geradora de $\mathrm{SO}_{2}$, inoculado com suspensão de $B$. cinerea; empregando o delineamento inteiramente casualizado, arranjado em esquema fatorial (ausência / presença de $\mathrm{SO}_{2}$ x ausência / presença de Botrytis), com cinco repetições e quatro cachos por repetição. Após 30 dias de armazenamento refrigerado e sete dias sob temperatura ambiente $\left(22^{\circ} \mathrm{C}\right)$, avaliou-se a incidência de mofo cinzento, degrana e características físico-química das bagas. A incidência de mofo cinzento em uvas 'BRS Nubia' diminuiu com o uso de folhas geradoras de $\mathrm{SO}_{2}$ durante o armazenamento refrigerado. A perda de massa das bagas foi maior nos tratamentos sem folhas geradoras de $\mathrm{SO}_{2}$ após 30 dias de armazenamento refrigerado e 7 dias de prateleira. A firmeza das bagas, a concentração de sólidos solúveis (SS), acidez total (TA), SS/TA e antocianinas totais não foram afetadas pelos tratamentos com folhas geradoras de $\mathrm{SO}_{2}$. No entanto, houve aumento na porcentagem de degrana das bagas nesses tratamentos. Não foi observada perda significativa de qualidade das uvas 'BRS Nubia' mantidas em temperatura ambiente por um período de 7 dias, após os 30 dias de armazenamento refrigerado.

Palavras-chave: Botrytis cinerea. Dióxido de enxofre. Qualidade do fruto.

In response to the fresh market, where consumers demand products of high quality, the maintenance and improvement of fruit quality during postharvest life have become increasingly important in recent years. Among these fruits, grapes have been recognized to have a wide range of compounds that improve health, such as phenolic compounds that neutralize free radicals (Colombo et al., 2020).

'BRS Nubia' is a seeded hybrid table grape released by Embrapa Grape and Wine, Brazil, with black color and neutral flavor. It is a highly productive cultivar that grows large and crunchy berries (Maia et al., 2013). This grape cultivar loads large $(\sim 0.7 \mathrm{~kg})$ and slightly compact bunches, demanding thinning techniques to reduce compactness (Silvestre et al., 2017). Compact bunches impair uniform fungicide spraying, which favors the growth of fungal spores or may become latent in the innermost area of the bunch developing at postharvest. Adapted to cultivation under subtropical areas with mild winters, 'BRS Nubia' can grow under a two-crop one-year system and is a strong candidate for overseas markets. However, in this intensive production system, the harvest period may coincide with periods of climatic conditions favorable to the development of postharvest fungal diseases, which can limit the long-distance transportation of fresh grapes (Youssef et al., 2015).

Among the table grapes postharvest diseases, the typical necrotroph attacking grapevines is Botrytis cinerea Pers. ex Fr., which can infect all green plant organs but is best known to cause gray mold in grapes and many other plant species (Carisse \& Van Der Heyden, 2015; Hashim, Youssef, \& AbdElsalam, 2019). Infections by B. cinerea can occur before harvest but can remain latent up to storage, when the pathogen takes advantage of disease development from higher relative humidity and low temperatures that slow down host defenses. The traditional control of gray mold infection consists of field application of synthetic fungicides during the crop growing cycle (Romanazzi \& Feliziani, 2014). 
Several families of synthetic fungicides are available to control gray mold infections (Romanazzi \& Feliziani, 2014). However, the control of gray mold is very difficult through synthetic fungicides, and due to safety reasons, they have been banished in many countries (Youssef et al., 2015). Thus, some environmentally friendly strategies are recommended to control gray mold in table grapes during postharvest, such as treatments with salt solutions (Youssef \& Roberto, 2014), $\mathrm{SO}_{2}-$ generating pads, and cold storage (Ahmed et al., 2019; Chaves et al., 2019; Youssef et al., 2015).

However, aiming to maintain the quality of the harvested product during transport, the selection of $\mathrm{SO}_{2}$-generating pads should be judicious, avoiding causing toxic effects to the consumer or changes in the sensory profile of the grapes. Additionally, the level of active ingredients must be appropriate to avoid damaging the fruit or impairing its flavor. Thus, information regarding 'BRS Nubia' table grapes during cold storage in relation to gray mold development has not yet been explored, and it is a very important issue for long distance and overseas markets. In this context, the objective of this work was to evaluate the control of gray mold of 'BRS Nubia' table grapes using $\mathrm{SO}_{2}$-generating pads and the effect on bunch quality during cold storage and shelf-life periods.

Bunches of 'BRS Nubia' table grapes were harvested in mid-May 2016 from a two-year-old commercial vineyard in Marialva, state of Parana, South Brazil (23⒉'S, $51^{\circ} 47^{\prime} \mathrm{W}$, altitude $570 \mathrm{~m}$ ). The vines were grafted on 'IAC 766 Campinas' rootstock, trained on overhead trellis with $18 \%$ plastic mesh covered, and spaced at a distance of $2.5 \times 9.0 \mathrm{~m}$ apart

Botrytis cinerea was isolated from infected grapes showing typical gray mold symptoms, purified and identified morphologically and molecularly, as described by Youssef and Roberto (2014). The isolates were maintained on PDA slants and stored at $4{ }^{\circ} \mathrm{C}$ for further use. Fungal mycelia were harvested from 2-week-old PDA cultures of B. cinerea grown at $23 \pm 1{ }^{\circ} \mathrm{C}$. A volume of $5 \mathrm{~mL}$ of sterile water containing $0.05 \%(\mathrm{v} / \mathrm{v})$ Tween 80 was added to a Petri plate culture. The mycelium was gently dislodged from the surface with a sterile glass rod and crushed with a mini processor. The mycelium suspensions were diluted with sterile water, and the concentration was determined with a haemocytometer. Further dilutions with sterile water were made to obtain the desired concentration. A $B$. cinerea suspension $\left(10^{6}\right.$ mycelium sections per $\left.\mathrm{mL}\right)$ was used for grape inoculation.

Bunches of 'BRS Nubia' table grapes of approximately $0.720 \mathrm{~kg}, 14.1{ }^{\circ} \mathrm{Brix}, 0.8 \%$ tartaric acid and $14.8 \mathrm{mg} \mathrm{g}^{-1}$ anthocyanins were harvested in the morning and selected manually to remove the damaged berries. Bunches were submitted to the following treatments: cold storage at $2{ }^{\circ} \mathrm{C}$ (control); cold storage at $2{ }^{\circ} \mathrm{C}$ with an $\mathrm{SO}_{2}$-generating pad; cold storage at $2{ }^{\circ} \mathrm{C}$ and inoculated with a $B$. cinerea mycelium suspension; and cold storage at $2{ }^{\circ} \mathrm{C}$ with an $\mathrm{SO}_{2}$-generating pad and inoculated with a $B$. cinerea mycelium suspension. The bunches that were inoculated with $B$. cinerea mycelium suspension were previously disinfested according to Chaves et al. (2019). For $\mathrm{SO}_{2}$ treatments, one generator pad measuring $13 \mathrm{~cm} \times 23 \mathrm{~cm}$ per box provided with fast and slow release phases of sodium metabisulfite $\left(\mathrm{Na}_{2} \mathrm{~S}_{2} \mathrm{O}_{5}\right), 98 \%$ (Matesa $^{\circledR}$, Grapeguard, Chile) was used during the cold storage period and subsequently removed at the beginning of shelf life. The experiment was conducted in a complete randomized design with five replications per treatment using four bunches per experimental unit. A factorial arrangement (absence/presence of $\mathrm{SO}_{2}$ pads $\times$ absence/presence of Botrytis inoculation) was applied.

The inoculation was carried out by spraying the mycelium suspension, and the bunches were left to dry at room temperature $\left(22 \pm 2{ }^{\circ} \mathrm{C}\right)$ for $1 \mathrm{~h}$ and placed into carton boxes $(13 \times 30 \times 40 \mathrm{~cm})$. The boxes were covered with colorless plastic bags and stored in cold chambers for 30 days at $2 \pm 1{ }^{\circ} \mathrm{C}$ and 
high $\mathrm{RH}$, followed by a 7-day period of shelf life at $22 \pm 2{ }^{\circ} \mathrm{C}$. By the end of 30-day cold storage and 7-day shelf-life periods, the following variables were evaluated for grape quality measurements:

1. Gray mold incidence and shattered berries: The incidence of gray mold on bunches was measured according to the following formula: disease incidence $(\%)=$ (number of decayed berries per bunch/total number of berries per bunch) $\times$ 100 (Youssef \& Roberto, 2014). Additionally, we evaluated the percentage of shattered berries per plot as follows: shattered berries $(\%)=$ (number of shattered berries per plot/total number of berries per plot) $\times 100$.

2. Physicochemical analysis: Weight loss (\%) was calculated as a percentage of bunch weight at the beginning and end of the cold storage/shelflife period. The difference as a percentage from the initial weight was calculated [weight loss (\%) $=($ initial weight - weight at examined date/initial weight $) \times 100]$.

Berry firmness $(\mathrm{N})$ analysis was performed for each period of evaluation with a texture analyzer TA. XT Plus. The measurements were taken from the equatorial position of 10 berries with pedicels per plot. Each berry was placed on the base of the equipment and compressed using a cylindrical probe with a diameter of $35 \mathrm{~mm}$ parallel to the base. A constant force of $0.1 \mathrm{~N}$ at a speed of $1.0 \mathrm{~mm} \mathrm{~s}^{-1}$ was applied to promote the cracking of the sample.

The chemical parameters of bunches were assessed by determining the soluble solids (SS, ${ }^{\circ}$ Brix), total acidity (TA, $\%$ of tartaric acid), SS/TA ratio, and total anthocyanin content in berry skin [mg of anthocyanins (as malvidin-3-glucoside) per gram of skin]. To perform the chemical analysis, five berries were collected from each box, totaling 15 berries per plot.
The data were subjected to analysis of variance (ANOVA), and the means were compared by Tukey's test at the $p \leq 0.05$ level.

No significant interaction $(p \leq 0.05)$ was found between the tested factors; however, isolated effects of $\mathrm{SO}_{2}$-generating pads and $B$. cinerea inoculation on some parameters were observed. For the gray mold symptoms in both conditions, at 30-day period of cold storage at $2{ }^{\circ} \mathrm{C}$ and at the end of 7-day of shelf life, the factor $B$. cinerea inoculation was evident in relation to non-inoculated treatments.

After the 30-day period of cold storage at 2 ${ }^{\circ} \mathrm{C}$, gray mold symptoms were observed in all treatments (Table 1). However, in the treatments without $B$. cinerea inoculation, the gray mold incidence was significantly lower $(4.40 \%)$ than that with inoculation $(11.05 \%)$, which shows the effectiveness of the use of mycelium suspension as an inoculum source. We also observed a significant effect of the $\mathrm{SO}_{2}$-generating pad on gray mold control. The lowest gray mold incidence $(5.08 \%)$ was recorded in grapes subjected to cold storage using $\mathrm{SO}_{2}$-generating pads, whereas the treatments without $\mathrm{SO}_{2}$-generating pads reached a midincidence of gray mold $(9.73 \%)$.

At the end of the 7-day shelf life period, the incidence of gray mold was higher than that of the 30-day cold storage period in all treatments (Table 1). Again, the $B$. cinerea inoculation in bunches showed a significant effect on disease severity compared to non-inoculated bunches. In contrast, no significant effect was found for the use of $\mathrm{SO}_{2}$ generating pads on gray mold control under shelflife conditions.

The use of $\mathrm{SO}_{2}$-generating pads contributed to an increase in shattered berries after 30 days of cold storage and at the 7-day shelf life period, reaching $5.96 \%$ and $10.36 \%$, respectively. On the other hand, no significant effect of $B$. cinerea inoculation was observed on shattered berries. 
Table 1

Gray mold and shattered berry incidence in 'BRS Nubia' table grapes submitted to different postharvest treatments at 30 days of cold storage (CS) and 30 days of cold storage with 7 days of shelf life

\begin{tabular}{|c|c|c|}
\hline \multirow{2}{*}{ Treatments } & Gray Mold (\%) & Shattered berries $(\%)$ \\
\hline & \multicolumn{2}{|c|}{ 30-day of cold storage } \\
\hline (-) $\mathrm{SO}_{2} \mathrm{pad}$ & $9.73 \mathrm{a}$ & $2.87 \mathrm{~b}$ \\
\hline (+) $\mathrm{SO}_{2}$ pad & $5.08 \mathrm{~b}$ & $5.96 \mathrm{a}$ \\
\hline (-) Botrytis inoc. & $4.40 \mathrm{~B}$ & 4.55 \\
\hline$(+)$ Botrytis inoc. & $11.05 \mathrm{~A}$ & 4.28 \\
\hline \multirow[t]{2}{*}{$\mathrm{CV}(\%)$} & 23.87 & 60.61 \\
\hline & \multicolumn{2}{|c|}{ 30-day of CS +7 days of shelf-life } \\
\hline (-) $\mathrm{SO}_{2} \mathrm{pad}$ & 13.45 & $5.31 b$ \\
\hline (+) $\mathrm{SO}_{2}$ pad & 11.39 & $10.36 \mathrm{a}$ \\
\hline (-) Botrytis inoc. & $5.21 \mathrm{~B}$ & 8.51 \\
\hline$(+)$ Botrytis inoc. & $18.99 \mathrm{~A}$ & 7.15 \\
\hline CV (\%) & 38.23 & 62.87 \\
\hline
\end{tabular}

(-) absence and (+) presence. Means followed by different letters, lowercase letters for $\mathrm{SO}_{2}$ pad and capital letters for Botrytis inoculation, differ significantly according to Tukey's test $(p \leq 0.05)$.

In relation to weight loss, no significant effects were recorded among the treatments at 30 days of cold storage. However, a significant reduction was observed for the $\mathrm{SO}_{2}$-generating pad treatment at the end of shelf life. In general, regardless of treatment, the weight loss ranged from 3.28 to $3.97 \%$ across the evaluated period (Table 2). Regarding berry firmness, Tukey's test $(p \leq 0.05)$ found no differences between the treatments in both periods of evaluation (Table 2).

No significant effects of $\mathrm{SO}_{2}$-generating pads or $B$. cinerea inoculation were found on the chemical parameters of the berries in the first evaluation at 30 days of cold storage. On the other hand, a significant effect of $B$. cinerea inoculation on SS, TA and SS/TA ratio parameters was observed at the end of 7 days of shelf life. Berries from non-inoculated bunches showed higher SS content and SS/TA ratio and lower TA than inoculated bunches. Interestingly, a reduction of $\sim 50 \%$ in the total anthocyanin contents was also observed when the periods were compared (Table 2).

Gray mold is the most important disease occurring postharvest in grapes, and it is responsible for major quality losses in grape bunches and berries in the main grape-growing areas of the world. In this trial, the percentage of gray mold incidence was evaluated under natural and artificial conditions, since field treatments are not efficient, and some infections that occur in the field remain quiescent during the growing season and develop after harvest (Romanazzi, Smilanick, Feliziani, \& Droby, 2016).

B. cinerea strains resistant to fungicides are very common and emphasize the need for an accurate adoption of Fungicide Resistance Action Committee (FRAC) guidelines, suggesting a limited number of applications per year. Furthermore, the traditional control of postharvest infection in cold-stored table grapes can be achieved by repeated fumigation with $\mathrm{SO}_{2}$ or using $\mathrm{SO}_{2}$-generating pads combined with polyethylene-lined grape containers (Youssef et al., 2015).

At 30 days of cold storage, the gray mold incidence under natural conditions (non-inoculated) was significantly lower than that under $B$. cinerea inoculation treatments, approximately 4 and $11 \%$, respectively. However, previous studies reported higher gray mold incidence on 'BRS Vitoria' 
table grapes grown in the same area, 20 and $40 \%$ under natural and artificial (inoculated) conditions, respectively (Youssef et al., 2015). Thus, this result may be associated with cultivar tolerance, climate conditions along with crop season, and field management. Regardless of the incidence level, it is crucial to control this disease, especially when grapes have to be stored in cold chambers before commercialization.

Table 2

Weight loss (WL), berry firmness (BF), soluble solids (SS), titratable acidity (TA), SS/TA ratio, and total anthocyanin content (ACNs) of 'BRS Nubia' table grapes submitted to different postharvest treatments at 30 days of cold storage and 30 days of cold storage with 7 days of shelf life

\begin{tabular}{lcccccc}
\hline \multirow{2}{*}{ Treatments } & $\begin{array}{c}\mathrm{WL} \\
(\%)\end{array}$ & $\begin{array}{c}\mathrm{BF} \\
(\mathrm{N})\end{array}$ & $\begin{array}{c}\mathrm{SS} \\
\left({ }^{\circ} \mathrm{Brix}\right)\end{array}$ & $\begin{array}{c}\text { TA } \\
(\%)\end{array}$ & SS/TA & $\begin{array}{c}\text { ACNs } \\
\left(\mathrm{mg} \mathrm{g}^{-1}\right)\end{array}$ \\
\cline { 2 - 7 } & \multicolumn{7}{c}{30 -day of cold storage } \\
\hline$(-) \mathrm{SO}_{2}$ pad & 3.34 & 8.48 & 14.11 & 0.58 & 24.64 & 11.85 \\
$(+) \mathrm{SO}_{2}$ pad & 3.53 & 8.56 & 14.20 & 0.57 & 25.32 & 13.83 \\
\hline$(-)$ Botrytis inoc. & 3.59 & 8.54 & 14.30 & 0.58 & 25.18 & 13.28 \\
$(+)$ Botrytis inoc. & 3.28 & 8.50 & 14.01 & 0.57 & 24.79 & 12.40 \\
\hline $\mathrm{CV}(\%)$ & 9.65 & 8.29 & 4.23 & 10.83 & 11.89 & 24.60 \\
\hline & \multicolumn{7}{c}{30 -day of cold storage +7 days of shelf-life } & \\
\hline$(-) \mathrm{SO}_{2}$ pad & $3.97 \mathrm{a}$ & 7.74 & 14.47 & 0.74 & 20.04 & 6.20 \\
$(+) \mathrm{SO}_{2}$ pad & $3.36 \mathrm{~b}$ & 7.90 & 14.46 & 0.74 & 20.31 & 7.28 \\
\hline$(-)$ Botrytis inoc. & 3.46 & 7.74 & $14.90 \mathrm{~A}$ & $0.70 \mathrm{~B}$ & $21.56 \mathrm{~A}$ & 7.29 \\
$(+)$ Botrytis inoc. & 3.86 & 7.91 & $14.03 \mathrm{~B}$ & $0.78 \mathrm{~A}$ & $18.79 \mathrm{~B}$ & 6.19 \\
\hline $\mathrm{CV}(\%)$ & 16.59 & 6.13 & 5.08 & 8.28 & 10.92 & 18.95 \\
\hline
\end{tabular}

$(-)$ absence and (+) presence. Means followed by different letters, lowercase letters for $\mathrm{SO}_{2}$ pad and capital letters for Botrytis inoculation, differ significantly according to Tukey's test $(p \leq 0.05)$.

The use of $\mathrm{SO}_{2}$-generating pads was shown to be a good strategy to control gray mold when 'BRS Nubia' table grapes are submitted to cold storage, with satisfactory results at the end of 30 days. These results agree with those reported by Ahmed et al. (2019), Chaves et al. (2019), and Youssef et al. (2015) for some table grape cultivars. Depending on grape cultivar, the results are even better, as those obtained for 'Red Globe' grapes, in which $\mathrm{SO}_{2}$-generating pads can control the disease up to a 4-month period under cold storage (Ozkaya, Dundar, \& Özdemir, 2008). However, in this specific case, the flavor of grapes declined slightly and remained acceptable until the 3-month period of storage.

$\mathrm{SO}_{2}$-generating pads did not show a significant effect on controlling the gray mold incidence at 7 days of shelf life. A possible explanation for this might be that the residual effect of $\mathrm{SO}_{2}$ in grape berries was very low and did not suppress pathogen development under shelf-life conditions. These results were expected because bunches were exposed to favorable conditions for disease development. In addition, the carton boxes filled with grape bunches remained opened along the shelf-life period, favoring $\mathrm{SO}_{2}$ gas dispersal.

Regarding the physical parameters of berries, the weight loss ranged from 3.28 to $3.97 \%$, and a low reduction in berry firmness was observed during the evaluated periods (Table 2). 'BRS Nubia' table grape has a large berry, approximately $11 \mathrm{~g}$ (Silvestre et al., 2017); for this reason, the low weight loss and reduction in berry firmness appear not to be commercially significant. 
In contrast, the chemical characteristics of berries, such as SS, TA, SS/TAratio, and anthocyanin content, were not affected by $\mathrm{SO}_{2}$-generating pads and $B$. cinerea inoculation over the cold storage period. However, at the end of shelf life, $B$. cinerea inoculation contributed to decreasing SS content. It seems possible that the greater severity of gray mold on the inoculated bunches affected the berry quality. Nevertheless, 'BRS Nubia' table grapes harvested in off-season crops showed adequate SS content for domestic and international markets (Table 2), which requires a baseline of $14{ }^{\circ}$ Brix or SS/TA ratio $\geq 20$ (Ministério da Agricultura, Pecuária e Abastecimento [MAPA], 2002; United Nations Economic Commission for Europe [UNECE], 2017).

Turning now to the experimental effect of $\mathrm{SO}_{2}$ generating pads on berry characteristics, such as SS, TA, SS/TA ratio, and anthocyanins, no significant differences were recorded among them. This result reinforces that $\mathrm{SO}_{2}$-generating pads decreasing gray mold on 'BRS Nubia' table grapes do not alter their chemical characteristics. In this context, 'BRS Nubia' table grapes were shown to be non-sensitive to the amount of $\mathrm{SO}_{2}$ gas released by the evaluated pads, except for the percentage of shattered berries. Similarly, the $\mathrm{SO}_{2}$-generating pad did not affect these parameters in 'BRS Isis' and 'BRS Vitoria' seedless grapes (Ahmed et al., 2019; Youssef et al., 2015). However, at high concentrations, this compound can cause bleaching or premature stem browning and may also damage the fruits, resulting in unwanted conditions.

At the end of shelf life, a decrease in total anthocyanin content of approximately 50\% was observed in comparison with the end of cold storage, which may have occurred because grapes were exposed to higher temperatures $\left(22 \pm 2^{\circ} \mathrm{C}\right)$ than those of cold storage. Similar results were recorded in 'BRS Vitoria' table grapes at the end of the shelflife period (Colombo et al., 2018). Anthocyanins are usually degraded when fruit are exposed to high temperatures and light conditions. The anthocyanins were relatively sensitive in açaí (Euterpe oleracea) fruit, where half of their content was degraded within 48 hours after harvest when fruit were kept at $30{ }^{\circ} \mathrm{C}$ (Rogez, Akwie, Moura, \& Larondelle, 2012).

In summary, regarding $B$. cinerea inoculation, it was possible to verify disease development at the end of cold storage and shelf life. The growth of gray mold on inoculated bunches impairs the bunch appearance, modulating the chemical parameters of the berries at the end of shelf life and depreciating the product for the domestic and international markets. A decrease in gray mold incidence was proven when the $\mathrm{SO}_{2}$-generating pads on 'BRS Nubia' table grapes were used during cold storage. Taken together, 'BRS Nubia' table grapes can be stored for up to 30 days under cold storage without significant changes in their chemical parameters.

\section{Acknowledgments}

Thiswork was supported by the ConselhoNacional de Desenvolvimento Científico e Tecnológico (CNPq), Coordenação de Aperfeiçoamento de Pessoal de Nível Superior (CAPES), and Empresa Brasileira de Pesquisa Agropecuária (EMBRAPA Grape and Wine).

\section{References}

Ahmed, S., Roberto, S. R., Youssef, K., Colombo, R. C., Shahab, M., Chaves, O. J., Jr.,... Souza, R. T. (2019). Postharvest preservation of the new hybrid seedless grape, 'BRS Isis', grown under the double-cropping a year system in a subtropical area. Agronomy, 9(10), 603. doi: 10.3390/agronomy9100603

Carisse, O., \& Van Der Heyden, H. (2015). Relationship of airborne Botrytis cinerea conidium concentration to tomato flower and stem infections: A threshold for de leafing operations. Plant Disease, 99(1), 137-142. doi: 10.1094/PDIS-05-14-0490-RE

Chaves, O. J., Jr., Youssef, K., Koyama, R., Ahmed, S., Dominguez, A. R., Mühlbeier, D. T., \& Roberto, S. R. (2019). Control of gray mold on clamshellpackaged 'Benitaka' table grapes using sulphur dioxide pads and perforated liners. Pathogens, 8(4), 271. doi: 10.3390/pathogens 8040271 
Colombo, R. C., Roberto, S. R., Nixdorf, S. L., PérezNavarro, J., Gómez-Alonso, S., Mena-Morales, A.,... Hermosín-Gutiérrez, I. (2020). Analysis of the phenolic composition and yield of 'BRS Vitoria' seedless table grape under different bunch densities using HPLC-DAD-ESI-MS/MS. Food Research International, 130, 108955. doi: 10.1016/j. foodres.2019.108955

Colombo, R. C., Souza, R. T., Cruz, M. A., Carvalho, D. U., Koyama, R., Bilck, A. P., \& Roberto, S. R. (2018). Postharvest longevity of 'BRS Vitória' seedless grapes subjected to cold storage and acibenzolarS-methyl application. Pesquisa Agropecuária Brasileira, 53(7), 809-814. doi: 10.1590/s01 00204x2018000700004

Hashim, A. F., Youssef, K., \& Abd-Elsalam, K. A. (2019). Ecofriendly nanomaterials for controlling gray mold of table grapes and maintaining postharvest quality. European Journal of Plant Pathology, 154, 377-388. doi: 10.1007/s10658-018-01662-2

Maia, J. D. G., Ritschel, P., Camargo, U. A., Souza, R. G. de, Fajardo, T. V. M., \& Girardi, C. L. (2013). BRS Núbia: nova cultivar de uva de mesa com sementes e coloração preta uniforme. (Comunicado Técnico, 139). Bento Gonçalves: EMBRAPA.

Ministério da Agricultura, Pecuária e Abastecimento (2002). Uva fina de mesa: normas de classificação. Brasília, Brasil: MAPA.

Ozkaya, O., Dundar, O., \& Özdemir, A. E. (2008). Evaluation of ethanol and sulfur dioxide pad effects on quality parameters of stored table grapes. Asian Journal of Chemistry, 20(2), 1544-1550.
Rogez, H., Akwie, S. N. L. T., Moura, F. G., \& Larondelle, Y. (2012). Kinetic modeling of anthocyanin degradation and microorganism growth during postharvest storage of açai fruits (Euterpe oleracea). Journal of Food Science, 77(12), 1300-1306. doi: 10.1111/j.1750-3841.2012.02996.x

Romanazzi, G., \& Feliziani, E. (2014). Botrytis cinerea. In Bautista-Baños, S., Postharvest decay: control strategies (pp. 131-146). Elsevier.

Romanazzi, G., Smilanick, J. L., Feliziani, E., \& Droby, S. (2016). Integrated management of postharvest gray mold on fruit crops. Postharvest Biology and Technology, 113, 69-76. doi: 10.1016/j.postharvbio. 2015.11.003

Silvestre, J. P., Roberto, S. R., Colombo, R. C., Gonçalves, L. S. A., Koyama, R., Shahab, M.,... Souza, R. T. (2017). Bunch sizing of 'BRS Nubia' table grape by inflorescence management, shoot tipping and berry thinning. Science Horticulturae, 225, 764-770. doi: 10.1016/j.scienta.2017.08.018

United Nations Economic Commission for Europe (2017). Standard FFV-19 concerning the marketing and commercial quality control of table grapes. Geneva, Switzerland: UNECE.

Youssef, K., \& Roberto, S. R. (2014). Applications of salt solutions before and after harvest affect the quality and incidence of postharvest gray mold of 'Italia' table grapes. Postharvest Biology and Technology, 87, 95-102. doi: 10.1016/j.postharvbio.2013.08.011

Youssef, K., Roberto, S. R., Chiarotti, F., Koyama, R., Hussain, I., \& Souza, R. T. (2015). Control of Botrytis mold of the new seedless grape 'BRS Vitoria' during cold storage. Scientia Horticulturae, 193, 316-321. doi: 10.1016/j.scienta.2015.07.026 